\title{
Analysis of Shiroro Hydro Electricity Dam (SHED) Community's Happiness: A Focus on the Physical Environment Using Probit Model
}

\author{
Musa Salihu Ewugi \\ Department of Economics, Ibrahim Badamasi Babangida University, Lapai - Nigeria \\ Email:msewugi@gmail.com \\ Mohammed Usman \\ Department of Sociology, Ibrahim Badamasi Babangida University, Lapai - Nigeria \\ Email: Muhfateh001@gmail.com
}

\section{Doi:10.5901/mjss.2016.v7n5p404}

Abstract

There have been technological advancements that have increased living standards over the years. This achievement is a product of perpetual challenge to meet human needs, most importantly to an end suffering, social injustice, welfare and promote happiness. In line with this thinking, SHED was installed in Shiroro community in 1990 with the goal of improving wellbeing or happiness of rural dweller living on the fringes of the Dam's reservoir and Nigerians in general. This study employs Probit Model to ascertain the happiness of the host community; the findings however, reveal that the community is not happy. It is recommended that a Dam Ecological Trust Fund be introduced to cater for all dam related environmental challenges and conclude that the study is outstanding for introducing happiness study viz a viz physical environment.

\section{Introduction}

Man and animals depend on the natural environment for livelihood. However, man's activities in the past decades has negatively affected the ecosystems and caused rapid degradation of the environment than at any other period in human history. This is largely due to fast growing population, exploitation of resources, advances in technology and the increasing demand for better living standard (MEA, 2005b). According to the earth system scientists, the world has entered a new phase, known as anthropocene. This (Greek words of "anthropo," for human; and "cene," for new or technology) connotes that the world has entered an age of technological curiosity. Its seven billion population burden has an implication on the natural environment. These have not only caused problems to the physical environment, but have also become a source of poverty, anxiety, and unhappiness to a substantial number of people across the globe (Helliwell, Layard, \& Sachs, 2013).

Indeed, over the years the advancement in technology has improved living standard globally. This has led to reduced infant mortality, reduction in fatal infectious diseases, increased availability of basic necessities of life, control over extreme weather conditions, and inventions that ease life like labour saving devices etc (Carr, 2011). In spite of these advances, technology continues to play roles in the destruction of the natural environment. Therefore, scholars continue to argue that material gains alone are not enough to fulfil our needs. In as much as the environment must be harnessed to meet human needs, it should be born in mind that these needs include reducing suffering and promotion of social justice for happiness. Thus, to have happiness, there is need to squarely face the challenges and preserve the natural environment (Helliwell et al., 2013).

One of the boldest steps ever taken to mitigate these challenges was the United Nations Conference on Environment and Development, popularly known as the Earth Summit or the Rio Declaration. The major achievement of this Summit was the adoption of protocols that guides nations towards sustainable development. One of the major guide among others is the Roman maxim sic utro et alienum non caedas, that is, one community or nation must not in the course of pursuing happiness encroach or hurt others. This was a bold global step at preventing or attending to global environmental problems (Mohammad, 2011).

Governments around the world take steps to improve the wellbeing and happiness of their citizens. Over the decades, the Nigerian government have established infrastructure and facilities to enhance the living standard of the citizens. One of such infrastructure is the Shiroro Hydro Electricity Dam (SHED) power generating plant. The Dam is 
located in the former Shiroro village, which influenced the naming of the dam. It is sited on the confluence of River Kaduna and its tributaries, Dinya River, and lies about sixty kilometers away from Minna, the capital city of Niger State in Nigeria.

The objective of this study is to assess the degree to which the individual households in the host community judge their quality of life or happiness in relation to the physical environmental consequences brought about by the installation of SHED in that community. Right from inception, at the commissioning ceremony of the Dam on the $21^{\text {st }}$ of June 1990, the then former President of Nigeria, Ibrahim Badamasi Babangida, declared that "the expansion of power supply is not only for economic development, but also to enhance the quality of living of the citizens" (Ayilla, 1990). In other words, happiness of the people was part of the goals. Therefore, how has this dam been able to translate to happiness of the host community in terms of the physical environment they live in, after about twenty years of its existence?

This study unlike previous studies (that based their analysis on the externalities of dam on the people and around SHED) is outstanding for extending its analysis to cover both the immediate dam environ (treatment group) and outside it (control group). It further approaches the issues under investigation from happiness studies perspective in relation to physical environment which, to our knowledge is unique.

After introduction above, section two is a brief review of literature. Section three outlines the methodology of the study which established the estimation procedure that was used to measure the happiness status of communities proximal to SHED. The fifth part discusses the results and the final section offers recommendations and concluding comments.

\section{Literature Review}

Man's curiosity and manipulation of the natural environment has resulted in economic growth. This has lead to happiness of man and in some cases otherwise. Happiness hinges on five main components - the basic materials needed for good living, good health, social development, security and freedom of choice and action. All these depend on the natural endowments of the environment and infrastructural provisions that are stimulated by human services, technology and institutions. However, in pursuit of these components for happiness, adverse effects sometimes occur to the ecosystem that results in otherwise (MEA, 2005a).

Usman, and Ifabiyi (2012) are of the view that there are two schools of thought with regards to the issue of environmental sustainability - the strong and weak. The strong school believes that pursuit of development must not be injurious on the environment, and that resources are better left untapped. However, the weak school on the other hand, is of the opinion that it is a give and take issue. That is, exploitation should be base on trade-off between resource development and deployment to a limit that permits harmonious coexistence between social, economic and environmental activities.

Helliwell, Layard, and Sachs (2013) are of the opinion that economic growth is has short run gains to wellbeing with long run cost or pains to the environment, which by implication is detrimental to happiness. The U.S. GNP per capita has increased by about three folds since 1960 but the average happiness remained same over this half a century due largely to environmental damages in the processes of the achievements.

Pursuits of happiness say by damming (for development) do not only affect the environment, but generates social and economic tensions. According to Sophie (2007) and Beck, Claassen and Hundt (2012) dam communities mostly suffers displacement, usually have weak voices, and lose of traditions and cultural practices. Moreover, at the end negligence usually leads to irreversible loss of species and ecosystems that is detrimental to happiness.

Nature relatedness is a significant positive predictor of happiness. Findings of Zelenski and Nisbet (2014) suggest that nature relatedness is distinct in producing happiness and could even be increased if nature relatedness is facilitated. MacKerron and Mourato (2013) provided a new line of evidence on the links between nature and happiness. They found estimated relationships of happiness greater in natural environments. According to Costley, Friend, Meese, Ebbers, and Wang (2011) close relationships and good natural environments without technological distortions contributes to women sense of happiness.

\section{Methodology}

\subsection{Source of data}

This study is based on probit model where $y$ is a binary response, taking on the values zero and one, as an indication whether certain event has occurred. Whatever, is the definition of $y$, traditionally $y=1$ and referred to as success while $y$ 
$=0$ as a failure (Wooldridge, 2010). Specifically, probit model is run where independent variables are dichotomous.

The data was sourced from Shiroro community i.e. the site of the Dam (Treatment Group) and Gurara community (Control Group) along River Kaduna - no dam. The choice of Gurara River as Control Group did not only serve as probit dichotomous feature to the Treatment but it's one among the three major rivers (Rivers Niger, Gurara and Kaduna) that pass through Niger State free of dam where there is no dam (no treatment). It also fulfills the selection criteria of likely distance of $60-70$ miles between the two points and share similar socio economic characteristics and even language (Aleseyed, Rephann, \& Isserman, 2003; Bryceson, Bradbury, \& Bradbury, 2008; Frankfort-Nachmias \& Nachmias, 2007).

Measurement of happiness in terms of physical environment was via questionnaire instrument. The questionnaire provided for two-optioned chain of questions of yes and no under each independent variable. This is capped with a 4point likert scaled World Value Survey (WVS) question of Taken all together, how happy would you say you are? - Very happy, Quite happy, Not very happy and Not at all happy. The dependent variable assumed binary faction with options of 1 where positive response (yes) and 0 where otherwise (no). Where $1=$ collided very happy and quite happy and $0=$ Not very happy and Not at all happy. The dependent variable Happiness is a product of collided WVS.

To obtain the independent variables, literatures supposed that world population and the keen perpetual interest at discoveries of better conditions of living result to anthropocene. This leads environmental problems that threatens global happiness (Helliwell et al., 2013). Dams are associated with diseases and infections (Mudzengi et al., 2012). Women feel stress free and well nourished in natural environment, which ignites their happiness (Costley et al., 2011). People living in Dam communities usually have weak voices and experience loss of ecological species (Sophie, 2007). Thus, installed Dam and no Dam (GRP_DAM), flood externality (ENVFD), change in the environment (ENVCHNG), change or alternating job for risk in Agriculture (ENVAGRSK), influence of urbanisation (ENVURBN), declinening wild life variety (ENVBMIT) and infections (ENVILNES) are measuring tools for physical environment. Thus, substituted in equation (1) one after the other respectively as shown below.

Literatures had been inconsistent about happiness of people viz a viz their environment. For instance, Halliwell et al,(2013) opined that growth and development leads to happiness in the short run (while in the long run, there is unhappiness and destruction of the natural environment). Happiness is greater in a natural environment (MacKerron \& Maourato; 2013 Costley et al, 2011). Thus, the statements of hypothesis that Shiroro Hydro Electricity Dam did not significantly improve the host community's happiness as measured by the physical

Estimated coefficients in probit model are not interpreted directly; rather-marginal effect is worked out for such. However, to achieve the objective of ascertaining the impact of SHED on the happiness of the host community based on environment, Dam as a variable need to be interacted against all other independent variables. But it's wrong to use marginal effect to interpret interaction terms, rather interaction effect computed with Stata command inteff (Ai \& Norton, 2003; Norton, Wang, \& Ai, 2004).

The interaction of probit model where dependent variable y is a dummy variable, the conditional mean of the dependent variable is as thus:

$$
E\left\{y / x_{1}, x_{2}, X=\Phi\left(\beta_{1} x_{1}+\beta_{2} x_{2}+\beta_{3} x_{1} x_{2}+X \beta\right)=\Phi(u)\right.
$$

Where $\Phi$ is the standard normal cumulative distribution, $u$ denotes the index $\beta_{1} x_{1}+\beta_{2} X_{2}+\beta_{12} X_{1} X_{2}+X \beta$. where $X \beta$ denotes other variables including demographics and the error term.

There are four important implications/assumptions of interaction for nonlinear models - the interaction effect could be nonzero, even if the two interact variables $=0$. The statistical significance of the interaction effect cannot be tested with a simple $t$ test on the coefficient of the interacted. Others are the interaction effect is conditional on the independent variables and the interaction effect may have different signs for different values of covariates i.e. $\beta_{12}$ (Ai \& Norton, 2003; Norton et al., 2004).

\subsection{Population and Sampling}

One of the administrative units in Nigeria is Local Government Area. The locations of the study are three Local Government Areas (LGAs) in Niger State. They are Shiroro and Muya LGAs which are the catchments of the dam (Treatment), and the third is Gurara LGA (Control). The populations of Shiroro, Muya and Gurara LGAs are 235,665, 103,461 and 90,879 respectively (NPC, 2010). In order to arrive at a sample size of the research units - that is villages the population of the sampling frames was determined by ascertaining the numbers of small political units called wards in the LGAs. There are 15, 11 and 11 wards in the LGAs respectively. The average of population frames per LGA was calculated to be $15,711,9,406$ and 8,262 per ward respectively.

Therefore, the population frames of 3 wards each (since two LGAs are involve in treatment group) in Shiroro and Muya LGAs (treatment group) are 47,133 and 28,217 and 5 wards of 41,310 in Gurara LGA (control group) were 
randomly selected. In other words, averages of 3 wards or population frames each put together in treatment group and 5 in control group made up the population that cover the research units of 10 villages each, selected for questionnaire administration. This is elaborated in the Table 1 below:

Table 1: Population and sampling

\begin{tabular}{|c|c|c|c|c|c|c|}
\hline $\begin{array}{l}\text { Local Government } \\
\text { Area (LGA) }\end{array}$ & Population & $\begin{array}{c}\text { Wards as } \\
\text { Sample Frame }\end{array}$ & $\begin{array}{c}\text { Average population } \\
\text { per ward }\end{array}$ & $\begin{array}{c}\text { Selected } \\
\text { sample frames }\end{array}$ & $\begin{array}{c}\text { Population of selectec } \\
\text { sample frames }\end{array}$ & $\begin{array}{c}\text { Research units } \\
\text { or Villages }\end{array}$ \\
\hline Shiroro & 235,665 & 15 & 15,711 & 3 & 47,133 & 5 \\
\hline Muya & 103,461 & 11 & 9,406 & 3 & 28,217 & 5 \\
\hline Gurara & 90,879 & 11 & 8,262 & 5 & 41,310 & 10 \\
\hline
\end{tabular}

In line with Baron and Kenny in Sekaran and Rogers (2010), 383 and 380 sample sizes were found to be adequate for the sampling frames of both the treated and control groups. However, one thousand and sixty-eight (1068) questionnaires were administered across the two groups with an increase of $40 \%$ (in questionnaires) to give room for non-response in line with Kotrlik and Higgins (2001) and given the peculiar nature of Nigeria's poor questionnaires response attitude (Adomi, Ayo, \& Nakpodia, 2007).

The sampling method adopted for this study is judgmental sampling technique. The selection of units of population was done based on the knowledge that the elements are the most representatives of the population (Anderson, Sweeney, \& Williams, 2011; Sekaran \& Roger, 2010). Only wards with villages within the range of 5 kilometers from the Dam and villages were systematically selected. The adoption of this sampling technique is aimed at optimizing the quality of the result since the selected units are most affected by the externalities of the Dam.

Distributions of the questionnaires were targeted at households. They were followed to their respective households and since the majority of the villagers are non-literate, the research assistants interpreted and filled in their views. The administration of the questionnaires was double-faced - filling of questionnaire and a follow up focus group discussion with the families as tail part of the questionnaires (section c) provided room for writing or jotting their opinions.

\section{Findings and Discussions}

In order to get to know how SHED impact on the happiness of the host community using Physical Environment (PEV), the variable grp_dam (Dam) is interacted with all other independent variables, one after the other for interaction effect. For example, where grp_dam is interacted with envfd, that is, grp_dam.envfd = Genvfd ("G" signifies combination of dam to other variables).If the coefficient happen to be positive or negative, the effect of the dam is said to have increase or decrease happiness respectively. Probit model for interactions is for concerned variable after which (inteff) Stata command is invoke to generate interaction effect. The results of the interaction effects are as in Table 2 below:

Table 2: Probit estimates of happiness in terms of PEV with interaction effect

\begin{tabular}{|c|c|c|}
\hline \multirow{2}{*}{$\begin{array}{l}\text { Variables } \\
\text { Dep. Var: Happiness } \\
\text { Indep. Variables }\end{array}$} & \multirow[b]{2}{*}{ Probit Coefficients } & \multirow[b]{2}{*}{ Interaction Effect } \\
\hline & & \\
\hline Genvfd & $\begin{array}{c}-0.632^{\star \star *} \\
(0.256)\end{array}$ & $\begin{array}{c}-0.165^{\star \star \star} \\
(0.048)\end{array}$ \\
\hline Genvchnge & $\begin{array}{l}-0.250 \\
(0.363)\end{array}$ & $\begin{array}{l}-0.030 \\
(0.049)\end{array}$ \\
\hline Genvagrisk & $\begin{array}{c}0.560^{\star * \star} \\
(0.209)\end{array}$ & $\begin{array}{c}0.202^{\star \star \star} \\
(0.048)\end{array}$ \\
\hline Genvbmit & $\begin{array}{c}-0.555^{\star \star \star} \\
(0.229)\end{array}$ & $\begin{array}{c}-0.200^{\star * \star} \\
(0.038)\end{array}$ \\
\hline Genvurban & $\begin{array}{c}-0.169^{\star * \star} \\
(0.215)\end{array}$ & $\begin{array}{c}-0.223^{\star \star \star} \\
(0.037)\end{array}$ \\
\hline Genvilnes & $\begin{array}{l}-0.443^{\star \star} \\
(0.203)\end{array}$ & $\begin{array}{l}-0.148^{\star \star \star} \\
(0.037)\end{array}$ \\
\hline
\end{tabular}

The standard error in parenthesis, ${ }^{*},{ }^{* *}$, ${ }^{* *}$ represents $10 \%, 5 \%$ and $1 \%$ significant levels respectively. 
Table: 2 connote the result of each independent variable as singled out against the installed dam (grp_dam) as a variable to be able to ascertain the degree of influence it has on each of the independent variables. Each interaction result generates two graphs that connote the interaction effect and significant levels. The graphs are the explicit picture of the interaction effect as it concerned all the observations or households. The table result might not necessarily be the same with the interaction effect based on the assumptions of the model.
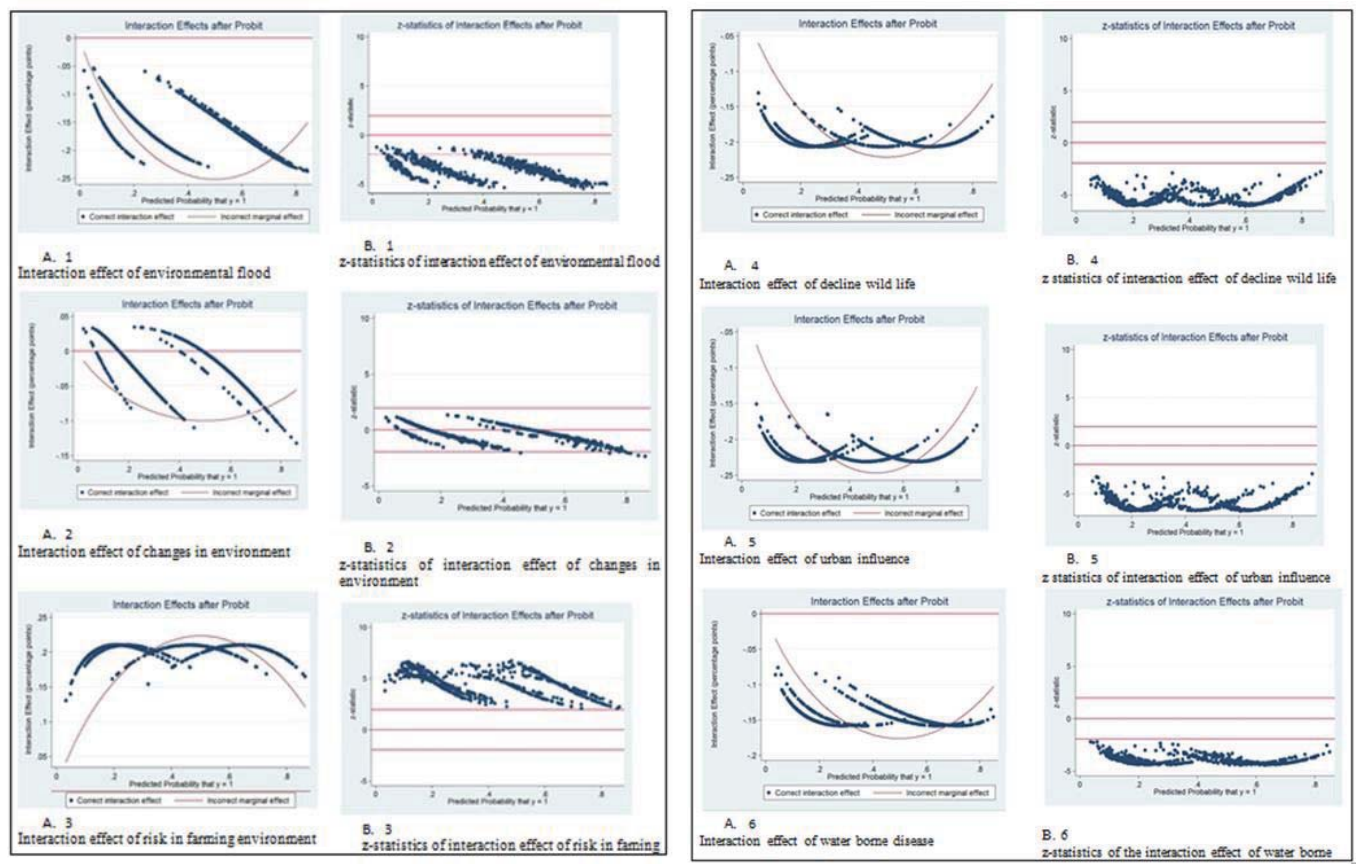

Figure: A \& B: Interaction effect and z-statistical of the independent variables

\subsection{Flood}

The coefficient of variable environment's flood interacted (Genvfd) with the dam (Table 2) is negative and significant at 1 percent (-0.632). This connotes that flood constitute a likely physical environmental problem that lowers the happiness of the community. On magnitude command of inteff, the value of interaction effect is negative $(-0.165)$ and varied widely in the observations from 0 - beyond 0.8 (see Figure A.1). The interaction is statistically significant at 1 percent level and varied widely. This goes to mean that people's predicted probability of happiness is lower in respect with dam prompt flood in the community and this stretch from 0 to beyond 0.8 (Figure A.2).

This decline happiness in SHED community might not be unconnected with increased physical environmental problems. Flood as a physical environmental problem occasionally torments the farmers who live by riverbanks. They sometimes experience large scale flood and have their season's crops submerged in water. This often happens during peak period of the rainy season. Sometimes, this type of flood submerges plants and crops for days and harms not only the plants but also the entire ecosystem. This has not only contributed to the destruction of the environment but has also increased the poverty level of the community. In other words, the families get distorted subsistence during flood years; and survival becomes very hard, as there is always no compensation from the dam authority.

\subsection{Changes in environment}

As rightly aforementioned, allowing farmland to stay fallow is no longer feasible in the community hence over utilization of available land makes infertility and change in the physical environment visible. Thus, the probability of decline or lower 
happiness of the community (Table 2) resulting from visible changes in the physical environment (Genvchnge) is negative in the interaction terms. The result is $(-0.250)$ but statistically insignificant.

The interaction effect value although, negative and statistically insignificant $(-0.030)$ too, the interaction effect as in Figure A.2 is not the same. The effect of the interaction actually connotes that the happiness of the majority of the households has declined due to the changes in the environmental physical features as shown in the statistical value. However, few households with predicted probability of happiness around $0-0.5$ have positive effect (Figure A.2). In contrast with the statistical value in table 4.1, the interaction effect is statistically significant (Figure B.2) for most of the observations. This indicates that changes in environmental features might favor few statistically; it has likely decline happiness effect on Shiroro community. In other words, looking on to the table alone does not tell the whole story of situation at hand rather sometimes misleading.

From the focus group findings, the probability of decline happiness by implication is that, even though, SHED brought along with it increase irrigation and fishing opportunities, the typical Gbagi (natives) farmer is more interested in the subsistence upland farming. Therefore, the resultant host community reaction from this physical environmental change is migration of the Gbagis to Nupe and other communities of the State in search of farmland. The Gbagis who are known to be confined to their homeland before Treatment are now all over the neighboring Nupe land in the state. The majority are now settled in villages around Lapai, Agaie, Bida, Mockwa and Katcha. Migration is sometimes embarked on by entire extended family while in some cases it involves only a portion of the extended family especially the youth.

Importantly, the implication of the migration is that, the dam has brought with it environmental problems that have succeeded in separating families and friends of the community, which in turn has negative consequence on the happiness of the community. In line with Donan et al., (2008), government policy that facilitates geographically mobility weakens networks of family and friends; and hence affect happiness negatively.

\subsection{Farming risk}

Farming risk due largely to environmental problems that serve as basis of some households change of occupation or combining more than one job (Genvagrisk) has positive effect at 1 percent significant level in the interaction term (0.560 - Table 2). This result implies, changing job or depending on more than one job due to environmental problems that are threatening to farming or risk to farming occupation have probability of increase happiness in the community.

The mean interaction effect connotes positive effect $(0.030)$ at 1 percent significant level and varied widely covering from 0 to beyond 0.8 (Figure A.3). In terms of significant effect of the interaction, the graph (Figure B.3) portrays that all the observations predictions of happiness status of community in respect to farming risk is not statistically significant. Therefore, depending on information solely in the table is sometimes misleading. In other words, the interaction effect could be said to be insignificant as portrayed by the graph.

The focus group discussion findings revealed that there has been distortion in shifting cultivation farming system that has being in existence. Now, the dam consumes a large portion of the farmlands therefore, land can no longer go round to accommodate the traditional farming system. Furthermore, some few settlements, like part of Guni, Kapana and Zumba that were resettled had no enough farmland provisions to accommodate the traditional farming system.

There is also alluvial plain flood, which is an annual risk. Farmers' plant maize on the alluvial plains or river banks at beginning of every rainy season knowing full well that it may be swept away by flood. The early rainfall moist keeps the river banks moist for about 3 months before the rainy season proper begins. Farmers patronize the alluvia plain of the riverbanks in order to have the advantage of early harvest of maize. As rainfall is subject to the vagaries of nature, if it comes earlier than forecasted, the chances of losing the produce to flood that year will higher than the previous and vice versa.

The aforementioned flood problems are occupational risks that sometimes compel farmers to combine farming with other jobs like fishing, trading, craft works etc. Some even change their jobs entirely due to the unpredictable and for risky nature of farming seasons. This might have made up the positive effect in the Figure A.3 above. However, the fact is that flood is a nuisance, which constitutes a major threat to farming (dominant occupation) within the community. Therefore, the positive effect of the interaction is not statically significant (Figure B.3) due largely to the pain taken or uncertain situation of farmers in the community.

\subsection{Loss of biodiversity}

The effect of the interaction terms between dam and decline wild life (Genvbmit) is negative -0.555 and statistically significant at 1 percent (Table 2). On invocation of inteff for the magnitude, mean interaction effect connotes negative 
effect $(-0.200)$ at 1 percent significant level and varied widely covering from 0 to beyond 0.8 (Figure A.4). This implies that the probability of the predicted happiness in terms of loss of biodiversity is lower.

In terms of statistical significance of the interaction effect, just as in Table 2, the graph connotes that all observation of the household prediction is statistically significant (Figure B.4). In other words, there is likely lower happiness in the community resulting from decline in the variety of wildlife.

From the focus group discussions, this lower state of happiness might not be unconnected to gross decline in animals and their species in the locality due largely to the dam's distortion of the ecosystem. This distortion affects the community's occupation of hunting which also negatively affect their income streams. In the words of Ezeazu (1998) "...the people were given just N2000 (about N8 to \$1 then) as compensation per adult persons while being re-located to sites less favorable for farming, fishing and hunting." There is gross reduction in the number of wide life as compare to before construction of the dam because of sudden change in the ecosystem. Hunters in the communities are no longer in business as usual because the habitat of the wild has been submerged in the dam. Hunting use to be a famous occupation (even though its combined with farming) in villages of Katehi, Guni, Sarkin-Pawa, Gofa, Ibro, Kaure, Maigu, Lagedo but with the installed dam, the structures are no more and that aspect of life is diminishing gradually.

\subsection{Urbanisation}

The coefficient on the interaction terms between group (dam) and urbanization or urban influence is negative (-0.169) and statistically significant at 1 percent. The coefficient of the interaction effect is -0.223 and statistically significant at 1 percent (Table 2) and varied widely from $0-0.8$ (Figure A.5). This implies that the predicted probability of household's happiness is lower in respect with urban influence. The probability of all the observations is statistically significant as clearly demonstrated in the Figure B.5.

The lower state of happiness might not be unconnected with the focus group revelations about threat of armed robbers and thieves that occasionally disturbed the community dwellers. It's a popular believe that Dogon daji or Dajin Gomna (between Alawa and Tegina to Kabata) harbors thieves who terrorizes the community occasionally. This they believe is due largely to the opening up of the community to the urban because of the dam, especially with the newly constructed bridge. The experiences theft is usually common with farm produce particularly yam and animals like sheep and cows. The thieves usually use pick-up vans to the farms in the night and steal yam (major crop of the community) tubers and in the morning, the farmer will have nothing to show for his annual effort. Thus, a new culture of transporting yam tubers from farm to homes after harvest and vice versa at planting season has emerged against farm storage habit.

Locally reared animals (mixed farming) like cows and sheep that usually wander around the villages with little or no control are occasionally stolen at night too. The nomads in the community are not left out in these experiences. They also occasional experience cattle rustling where farmers are forced to part with their animals, which is a social problem associated with opening up or urban influence.

\subsection{Water borne diseases (malaria)}

The interaction term between group (dam) and water borne disease is negative i.e. --0.448 at 5 percent significant level (see Table 2). On invocation of inteff for interaction effect, the result is same - negative effect with 1 percent significant level. This implies that the community's probability of happiness is lower in respect with water borne diseases most especially malaria. The result portrays same negative effect in the graph (Figure A.6), which varied across 0.1 to beyond 0.8. In terms of statistical significant, the predicted probability of all the observations is statistically significant (Figure B.6). That is, from 0.1 - beyond 0.8 are statistically significant.

From the findings in group discussion section, this might not be unconnected with the occasional problem of water borne diseases because of dependence of the rural populace on the river for domestic use, and increased cases of malaria fever due largely to over flooding during rainy seasons. This leave behind puddles of water and damp environment conducive for the breeding of mosquitoes.

\section{Summary, Conclusion and Recommendation}

In summary, the findings connotes that the SHED host community is not happy in terms of Physical Environment. The results of interaction effects are; the mean coefficient of interaction of flood (Genvfd) is -0.165 and significant at $1 \%$, farming risk (Genvagrisk) is 0.202 and significant at $1 \%$, decline wild (Genvmit) is -0.200 at $1 \%$ significant level. Others are urban influence (Gurban) is -0.223 at $1 \%$ significant level, visible environmental change (Genvchang) is -0.030 not 
significant (graphically majority of house hold predictions are within significant level) and diseases (Genvilnes) is -0.148 at $1 \%$ significant level (Table 2, Figure A\&B).

In conclusion, the statement of hypothesis that 'the installed SHED does not significantly improve host community's happiness through physical environment cannot be rejected. The evidences from the results of PEV as aforementioned proved that SHED community has lowered predicted probability of happiness. Meaning, the community's happiness in respect with the physical environment is worsened due to the installed dam. This finding is in line with the literatures; that dam victims are usually found to have weak voices, experiences loss of ecological species, loss tradition and cultural practices that are detrimental to happiness (Sophie, 2007). The displaced Chinese rural communities not only suffered environmental cost of near shore landslides, earthquake but also distortion of agrarian lifestyle (Beck et al., 2012).

The study therefore, recommends that government should establish Dam Ecological Trust Fund (DETF) as a matter of policy to handle all dam triggered environmental problems. The institution should be entitle to certain percentage of the Hydro Electricity Generations of the proceeds as her source of revenue, which would be use for flood compensations, forestall nature where possible and need be and provision of rural medical outfits in the host community. This framework is scored high in the education sector therefore, if introduce, will go along way at putting smiles on the faces of SHED host community.

\section{References}

Adomi, E. E., Ayo, B. T., \& Nakpodia, E. (2007). A better response rate for questionnaires: Attitudes of librarians in Nigerian University Libraries. phylosophy and Practce, $1-7$.

Ai, C., \& Norton, E. C. (2003). Interaction terms in logit and probit models. Economics letters, 80(1), 123-129.

Anderson, D. R., Sweeney, D. J., \& Williams, T. A. (2011). Statistics for Business and Economics. Mason, USA: South-Western, Cengage Learning.

Ayilla, M. (1990). IBB commissions Shiroro Dam, New Nigerian Newspaper, p. 1 and 3.

Ayogu, M. D. (2000). The political economy of infrastructure investments in Nigeria. Paper presented at the Annual Bank Conference on Development Economics, Washington, DC.

Beck, M. W., Claassen, A. H., \& Hundt, P. J. (2012). Environmental and Livelihood Impacts of Dams: Common Lessons across Development Gradients that Challenge Sustainability. International Journal of River Basin Management, 10(1), 73-92.

Carr, A. (2011). Positive psychology: The science of happiness and human strengths: Routledge.

Costley, C., Friend, L., Meese, E., Ebbers, C., \& Wang, L. J. (2011). Happiness, Consumption and Being. Research in consumer behavior, 11, 209-240.

Ezeazu, E. (1998). 15 Years is Enough: Shiroro Communities Fight Back. Community: The Quqrterly Publication of Community Action for Popular Participation, 03, 16-18.

Helliwell, J., Layard, R., \& Sachs, J. (2013). World happiness report.

Kotrlik, J. W. K. J. W., \& Higgins, C. C. H. C. C. (2001). Organizational research: Determining appropriate sample size in survey research appropriate sample size in survey research. Information technology, learning, and performance journal, 19(1), 43.

Mackerron, G., \& Mourato, S. (2013). Happiness is Greater in Natural Environments. Global environmental change, 23 (5), 992-1000.

MEA. (2005a). Ecosystems and Human Well-being: Scenarios Millennium Ecosystem Assessment. Island Press, Washington: The United Nations Environment Programme (UNEP).

MEA. (2005b). Ecosystems and human well-being: Synthesis (Vol. 5): Island Press Washington, DC.

Mohammad, N. (2011). Environment and sustainable development in Bangladesh: A legal study in the context of international trends. International Journal of Law and Management, 53(2), 89-107.

Mudzengi, B. K., Ejide, B., Tamuno, S. O., Iroh, W. O., Muchenje, F., Moruff, M., . . Salam, A. (2012). An Assessment of the SocioEconomic Impacts of the Construction of Siya Dam in the Mazungunye Area: Bikita Distrct of Zimbabwe. Journal of Sustainable Development in Africa, 14(4), 1-17.

Norton, E. C., Wang, H., \& Ai, C. (2004). Computing interaction effects and standard errors in logit and probit models. Stata Journal, 4, 154-167.

NPC. (2010). Population Distribution by Sex, States, LGAs, and Senatorial Districts. Abuja: Federal Republic of Nigeria.

Sekaran, U., \& Roger, B. (2010). Research methods for business: A skill building approach: John Wiley \& Sons.

Sophie, N. (2007). Addressing the Social Impacts of Large Hydropower Dams. Journal of International Policy Solutions, 7, 11-17.

Usman, A., \& Ifabiyi, I. (2012). Socio-Economic Analysis of the Operational Impacts of Shiroro Hydropower Generation in the Lowland Areas of Middle River Niger. International Journal of Academic Research in Business and Social Sciences, 2(4), 57 -76.

Wooldridge, J. M. (2010). Econometric analysis of cross section and panel data: MIT press.

Zelenski, J. M., \& Nisbet, E. K. (2014). Happiness and Feeling Connected The Distinct Role of Nature Relatedness. Environment and Behavior, 46(1), 3-23.

Ziri, R. (1996). 15 years is Enough; Shiroro Communities Fight back. Community: Quaterly Publication Of Community Action for Perticipation 03, 16 - 18. 